\title{
ON THE VIENNA CIRCLE IN EXILE: AN EYEWITNESS REPORT
}

During its most vigorous period, the Vienna Circle movement was, by and large, kept rather marginal by the political and academic forces in its European home; they tended to see it as a dangerous search, in the Enlightenment tradition, for a world conception that would be free from metaphysical illusions, free from the kind of clericalism that had a strangle-hold on state and university, and free from the romantic madness of the rising fascist ideology. The wonder, in fact, is that in its day, against such opposition, the Vienna Circle commanded adherence by such an array of distinguished intellectuals, even if they were only a small fraction of the total intelligentsia.

By sharp contrast, remnants of the Vienna Circle group that migrated to the United States in many cases eventually found colleagues and university administrations intrigued by and open to their continuing work. This essay, dealing with what was perhaps the most successful example of this transplantation into more accepting soil, bases itself on the personal eyewitness experience and selected documents in a particular case, that of the discussion group founded in Cambridge, Massachusetts; in fact it lasted fourteen years-two years longer than the official lifetime of the organized Vienna Circle in Europe (1924-1936).

Moreover, we shall be touching on another asymmetry between the experiences in Europe and the U.S.A. The details of the actual meetings of the Circle in Vienna are still largely unpublished, whereas within the compass of this essay I can give at least a glimpse of the participants and topics of the meetings in Cambridge which I had the good fortune to attend, beginning during the time when I was still at the graduate-student level.

I know of only two graduate students who were allowed at the original Circle's meetings in Vienna. One was Herbert Feigl, and the other a 20-year-old student of Hans Hahn, Rudolf Camap, and Moritz Schlick, named Kurt Goedel. We do know in general how the Circle tended to operate, both in its informal meetings and in the more formal Thursday sessions under Schlick. Thus Camap's pocket diary, kept at the University of Pittsburgh Library, has such entries as: 13 Nov. 1928, Discussed with Goedel in the Cafe from 5 to $9 \mathrm{pm}$, concerning foundations of mathematics. 30 Nov.: Morning in the Arkadencafe with Goedel, Waismann, Feigl, Natkin. On another day, Cafe Reichsrat with Feigl, Goedel, Waismann, on Goedel 's discovery of the incompleteness of the System of the Principia Mathematica.And finally, on 15

Jan. 1931, Goedel presents his work to the full group in one of the closed sessions in Schlick's circle. 1

All such activities were stopped five years later by the country's highest authorities. But the Circle did not disappear entirely. Many of its members emigrated to 
foreign countries where local scientists and scholars shared their ideas and fascinations, at least to some degree, and joined them in the resumption of their meetings and debates. In his autobiography, W. V. Quine-wbo should know, because in fact be was a visitor to and speaker at the original Circle's meetings in Vienna in 193233, as well as a participant at the analogous meetings in the Boston area in the 1940s and '50s-wrote of those latter occasions that they could be called "a Vienna Circle in exile."2

The United States was intellectually ready for the migration of the members of the cognate groups from Vienna, Prague, Berlin and other European centers such as Warsaw, Budapest, Paris, and Rome. It was prepared by virtue of the characteristic philosophical tradition associated with such names as C. S. Peirce, William James, and John Dewey. For example, Ernest Nagel in New York and Charles Morris in Chicago-both personally involved with the original Circle-were active hosts, and in the Boston area, there were sympathizers such as P. W. Bridgman, W. V. Quine, Dirk Struik, and Norbert Wiener.

As it happened, Bridgman and Quine were effectively the local arrangements committee for the Fifth International Congress for the Unity of Science, a summit meeting of the Circle and its sympathizers, which was held at Harvard University from September 3 to 9, 1939-just as war was breaking out in Europe. In the Harvard Archive's Bridgman collection is the original list of the large number of expected speakers (Figure 1), and it indicates the distinguished group that met at that bewildering moment of history. As if to accentuate the different attitude awaiting them on that shore, the Congress participants were greeted by the president of the university, James B. Conant. (It may have helped that Conant regarded Bridgman highly, with whom he had even co- authored a paper during Conant's graduate studies.) Many who had crossed the ocean for this meeting were to remain in the U.S., for example, Richard von Mises, who had just completed his bookKleines Lehrbuch des Positivismus. Philipp Frank had come earlier from Prague to do a lecture tour of the U.S., and of course he also stayed on. Other ex-Europeans who were interested in what was then called a "scientific approach to philosophy" came to join them.

Thus it came about that by the early 1940s there was in the Greater Boston area a critical mass of expatriates, including Leon Brillouin, Karl Deutsch, Giorgio de Santillana, Frank, Roman Jakobson, Gyorgy Kepes, Philippe LeCorbeiller, Wassily Leontief, George Uhlenbeck, Joseph Schumpeter, and Laszlo Tisza, all of whom later appeared on the roster of the meetings of the reconstituted Vienna Circle in Exile. (Herbert Feigl and Carnap-who had come earlier-and Hans Reichenbach also became centers of closely related groups in the U.S.A., far from Boston.)

The spark plug for instituting these meetings in the Boston area was the physicist and philosopher Philipp Frank, later to be the biographer of Einstein, whom Frank succeeded when Einstein left the German University in Prague in 1912. Frank bad been a principal participant both of the predecessor of the movement (1908-1912) and later of the mature form of the Vienna Circle in the 1920s and '30s. From 1939 on, he was a part-time lecturer on physics and philosophy at Harvard; but his burning urge to meet with like-minded discussants was undiminished. The drive to in- 
terdisciplinarity, in the Unity of Science tradition of positivism-so emphasized by Otto Neurath's work on the International Encyclopedia of Unified Sciencewas evident even in the name Frank gave the new meeting series: "Inter-scientific Discussion Group." (See Figure 2 for a typical letter of invitation.) The same attitude was evident also in the spread of competencies of the program committee members, and in the group's merciless striving for clarity, as in its announcement that on January 8, 1945, "Professor R. von Mises will lead a discussion on 'Sense and Nonsense in Modem Statistics.'" In the same spirit, the next meeting's invited speaker was Charles Morris, then in New York, who was asked to come and provide "precise terms for the often-made vague statements that scientists seek simplicity or economy in their theoretical work."

The expectations for the performance by a speaker were evidently high, and the tolerance for any "quasi-mystical" attitude was low. This appears also from an earlier letter which has survived from that series, in which the philosopher C. J. Ducasse at Brown University wrote to Frank on October 4, 1944. The speaker of the previous evening had been the historian and philosopher of science, Giorgio de Santillana of MIT. In Ducasse's view, de Santillana had apparently shown signs of believing in a "quasi-mystical, unanalyzable sort of event." Ducasse's letter also indicates that the old aim of the Vienna Circle and its Ernst Mach Verein-to missionarize among the general public-was still alive, for Ducasse offered to write "a little book addressed to the general reader, under such title as 'What is Science?"'. In the invitation to him to present just such an idea for discussion, he was admonished to keep in mind conveying to the public the idea of the unity of science, i.e., to "bring out the common elements in the methods used by scientists in different fields." That aim was of course an article of faith of the whole group throughout, harking back to the message in the Vienna Circle manifesto of 1929, Camap's Der logische Aujbau der Welt of 1928, the 1911 Manifesto of the Society for a Positivistic Philosophy, and even to a godfather of the whole movement, Ernst Mach himself.

Let me insert here some autobiographical remarks which might be useful. When I arrived at Harvard in 1943, to work in the war-time laboratories and in the instruction of radar, I happened to be assigned a desk in a room in Jefferson Physical Laboratory which primarily served as the office of Philipp Frank. Like everyone who met him, I admired this gentle scholar. He seemed to be a link in a charismatic chain going back to Ludwig Boltzmann, under whom he had started his $\mathrm{PhD}$ thesis, to his early patron Ernst Mach, ${ }^{3}$ and to his friend Einstein. At some point Frank invited me to attend these meetings of the Inter-scientific Discussion Group. When the war ended, I returned to my graduate studies, but also was promoted to be Secretary of the group, inheriting that office, together with the previous files, from a young associate of Norbert Wiener at MIT, Pesi Masani.

The list of speakers and topics of the first few meetings of the group include the following: Giorgio de Santillana, "The Real Difficulties of Empiricism"; Talcott Parsons, "Psychoanalysis and the Theory of Social Systems"; Richard von Mises, "Science and Nonsense in Modem Statistics"; Norbert Wiener, "The Brain and the 
Computing Machine"; George Wald, "Biology and Social Behavior"; C.J. Ducasse, "What is Science?"; John T. Edsall, "Stability and Flux in the Living Organism"; Y. K. Chao, "Symbology and the Chinese Language"; John T. Edsall, "Life Work of Dr. Walter Cannon, and Future Programs [of the group]"; Hudson Hoagland, R. W. D. King, and Wassily W. Leontief, "Relation of Hypothesis and Experiment in Different Sciences"; I. A. Richards, Samuel Beer, E. C. Kemble, P. LeCorbeiller, and E. S. Castle, "General Education." It is evident that there were no bounds to their curiosity.

A feeling of the actual discussions that took place in such meetings may be conveyed by the Secretary's summary for Dec. 17, 1945, when the discussion, Jed by Leon Brillouin, Jeffrey Wyman and W. J. Crozier-the last of these a student of Jacques Loeb--was on "Living Organisms and the Second Principle of Thermodynamics":

Brillouin pointed out that in many phenomena which are significant for life, such as burning of coal, combustion of sugar, there is a kind of potential mountain which prevents reaction which occurs only under "proper conditions." In all these cases the 2nd law gives no information about when the reaction will take place, nor how fast.

Bridgman raised the question as to whether the systems considered in biology were thermodynamics systems-that is, macroscopic systems with methods of determining their temperature, mass, etc. [Because of] the fact that the eye is excited by only four or five photons, the delicate synthetic processes of the cell would suggest that biological systems are not thermodynamical ones.

How is a biological system defined? The relevance of the environment to biological phenomena exhibits the difficulty. Are the parts of a living cell alive? Where is the boundary line between the living and the non-living?

The structural permanence and self-regeneration of living organisms was suggested as a distinguishing characteristic. But Frank inquired why one does not also on that basis regard an atom of iron as a living organism. There is no reason to suppose that the electrons, protons, etc. preserve their identity through the "life" of the atom. Frank stated that the probability of biology discovering any new physical laws is rather small because the units dealt with (cells, microorganisms) are too large. The epigram of Russell was quoted concerning the question of whether living organisms are anything more than a complicated system of atoms spinning in their orbits. "It is a political question."

One wishes there bad been a sound recording device in operation, and again at other meetings, for example when the general topic was the problem of Meaning, led by Roman Jakobson, Quine, and Bridgman.

Let us look more closely at the width of the spectrum of interests of this group. After circulation of a preliminary sheet to the members of the informal program committee in 1945, the final form of the listing of areas of interests for these meetings (Fig. 3) makes the important point that in addition to the logic of science, which one remembers to have been one of the central interests of the old Vienna Circle, there appear here as main topics explicitly also the psychology and sociology of science. So did the very first invitation letter that bas survived, dated 25 September 1944, which announced: "A group bas been formed at Harvard that is interested in 
considering science as a whole in tenns of the scientific temper itself, and in the study of the logic, psychology, and sociology of science."

All this is at variance with recent characterizations of logical empiricism. Particularly those who now dismiss that particular philosophy of science forget that an active concern to include in the understanding of science the lessons of history, psychology and sociology of science, so fashionable today, was current among those scholars--and not only in the mid-1940s; one only needs to look at the previous work of Otto Neurath, Hans Hahn, and Edgar Zilsel. ${ }^{4}$

I can underline this point by noting that when the rather informal Discussion Group was converted in 1947 into the Institute for the Unity of Science, which acted under the umbrella of the American Academy of Arts and Sciences in Boston, its charter defined its purpose as follows: "to encourage the integration of knowledge by scientific methods [and) to conduct research in the psychological and sociological backgrounds of science..."Writing in 1950,5Philipp Frank explained the reason for pursuing this goal in these words:

During recent decades, substantial progress has been achieved by considering the sciences as formal systems and by analyzing them from the logical and semantical viewpoint ... However, it has turned out more and more that these problems cannot be settled definitely on the basis of logical and semantical analysis. There remain always several possibilities for the choice of a formal system. Carnap contrasted recently in an excellent way the "internal" problems which can be solved by logic and semantics with the "external" problems. The latter ones put the question whether a certain formal system, as a whole, with the addition of a semantical interpretation, is useful for the orientation of man in the world of experience. Here we turn from the logical and semantical to the pragmatic viewpoint... What kind of argument do we call "pragmatic"? To get the answer we have to consider science as a human enterprise by which man tries to adapt himself to the external world. Then a "pragmatic" criterion means, exactly speaking, the introduction of psychological and sociological considerations into every science, even into physics and chemistry. It seems, therefore, that the sociology of science, the consideration of science as a human enterprise, has to be connected in a very tight way with every consideration which one may call logical or semantical.

As if to make quite sure that the point would not be lost, Frank ended by repeating it:"...by the combination of the logical and the sociological approach to science, all the needs which have produced traditional philosophy and metaphysics can be satisfied." The four issues of the Academy's Proceedings volume in which this article appeared contains essays in the same spirit. 6

As I have pointed out elsewhere, 7 the link between the I.U.S. and the Academy was not accidental, but yet another example of the symbiosis between the Europeans' urge toward Einheitswissenschaft and similar American tendencies. As

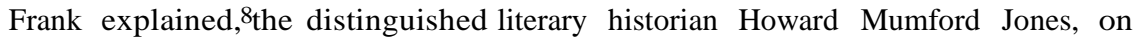
succeeding the astronomer Harlow Shapley as president of the American Academy, had expressed the hope in his October 1944 inaugural address of overcoming "the fractation of knowledge" through an encouragement of the "pressures toward unity", for which the Academy, which embraced members of all scholarly disciplines, seemed particularly well suited. A committee of the Academy to implement 
Jones's call soon agreed, calling for programs that would support the "synthesis of knowledge." In founding the Institute for the Unity of Science, Frank and his colleagues provided one of the more visible responses to this call. In his published "Greetings" of April 1950 to the first national meeting organized by the Institute, President Conant of Harvard again provided support by lending his prestige and by recording his welcome for this effort. He confessed to being "deeply interested in the unity in science", and saw its pursuit to be a precondition for achieving his plan for the General Education program in science for undergraduates, then being implemented at the College. 9

The energy and persuasiveness of the leaders of the movement were enormous, and they vigorously aimed to expand their claim to attention by other American scholars. An example is found in a letter of 29 October 1950, conveyed by Charles Morris on behalf of the Institute, to Robert K. Merton at Columbia University. They wrote him that the Institute planned to issue bibliographies on key fields of interest; therefore, the letter continued, "we wish very much that you would do one on the sociology of science." So years before that field had begun to draw general attention in academe, the Institute had targeted it, as well as engaging the obvious person to undertake a bibliography. 10

I think by now you have guessed a main point I want to make here: The Vienna Circle in Exile learned from the interests of those it encountered in its new surroundings, and adapted itself to them, while at the same time also taking every opportunity to propagate some of its older views. But I am getting ahead of my story. I want to tum to some documents that serve to give a taste ofthe meetings of the Interscientific Discussion Group, namely the attendance sheets that were circulated at most of the meetings. To give an example, Fig. 4 carries the names of persons at the fifth meeting of the Inter-scientific Discussion Group, held in February 1945, during which Norbert Wiener made the presentation noted before. Among the attendees were Walter Pitts, a mathematician working with de Santillana; Raphael Salem, a mathematician from France who returned there later on; the philosopher Aron Gurwitsch, a phenomenologist at Brandeis University; Philippe LeCorbeiller, a learned professor of electrical engineering from France; von Mises; Bridgman; Uhlenbeck; Kemble, the distinguished physicist; Felix Chemuschi, from the Division of Engineering at Harvard; and others.

The attendance sheet for the sixth meeting (Fig.5) adds to the sense of the number and variety of the participants. George Wald spoke on "Biology and Social Behavior", on March 21, 1945; there were present (among others) the sociologist Talcott Parsons, the biochemist John Edsall, the economists Paul Samuelson, Leontief, Haberler and Schumpeter; the astronomer Harlow Shapley; the physicist George Uhlenbeck, the electrical engineering professor, Ronald King; Bridgman; Norbert Wiener; I. A. Richards from England; A. Sprague Coolidge, physicist and chemist; and de Santillana. (Incidentally, of the thirty- three persons in that room that night, five later attained Nobel Prizes.)

The seriousness of the participants, their variety and their quality are astounding to anyone who looks through the attendance sheets of all the meetings. 11 The same 
persons come up frequently, the reason being in part that each invitee had to agree to come fairly regularly; otherwise, they would not be circulated again. Invitations to join were sent to anybody who was suggested within the group to be susceptible. (The mailing list of the people who had been contacted still exists.) Regular attendees could bring visitors; but if they failed to come a few times, they would be dropped. The Secretary's files contain earnest letters of excuse, for example from Edwin G. Boring, Henry A. Murray, and Crane Brinton.

I have already mentioned President Conant of Harvard twice-once when he welcomed the Fifth International Congress of the Unity of Science at its opening meeting on September 3, 1939, and again when he spoke about the relationship of the Unity of Science movement to his new General Education program at the April 1950 national meeting. I suspect that Philipp Frank, from the moment he arrived at Harvard in early 1939, communicated to Conant the idea that through the pursuit of unification one could achieve a different view of culture from the usual one of a university splitting into divisions and departments. Conant was ready to hear this. Early in 1936, then three years in office, he had given a talk in which he said he had noticed that year-by-year the catalogue of courses given at Harvard was getting thicker and thicker, that evidently a splintering of knowledge was occurring. He suggested that as administrator he longed to reverse this process. I feel sure that Frank saw his opportunity and told Conant that there is a way: through unification among the sciences and other areas of knowledge.

Evidently Conant thought the General Education program was a step in the same direction. The original idea, described in a book published by the Faculty Committee charged with designing the program (General Education in a Free Society, Harvard University Press, 1945), was that in the physical and biological sciences, in history, and in each of the other major fields, there would be one historically based survey course, each taught by a distinguished senior person, presenting an overall view of the whole field. Thus, when the program was implemented, George Wald gave a one-year course of this sort on biology; Philipp Frank taught one for more advanced students on philosophy of science; Kemble ran one on the physical sciences. LeCorbeiller and several others on the list of the Inter-scientific Discussion Group, including myself, were similarly involved.Conant himself, though busy as president, went into the classroom three times a week for his course "Nat. Sci. 4", and helped to develop textbooks for it, centered on case studies in the history of science. Thereby he provided also a role model for the faculty; moreover, he invited the heads of all those courses once a month to a splendid dinner followed by shop talk, which energized them even more. So the General Education program was yet another outlet for the unification ideal, at least for some of the faculty at Harvard.

The fact that the president of the university repeatedly showed his active interest in at least some aspects of the Vienna Circle in Exile suggests that I reemphasize a point made earlier in passing: When the storms of war had tossed remnants of the Vienna Circle on the shores of Harvard Square, MIT's Kendall Square and beyond, a strange reversal of fortunes occurred. Back in Europe, these scientists and scholars had been kept at bay by the higher authorities, and not much respected by some 
of their professional colleagues and by the bulk of the student-body. Arriving in America, many faced unfamiliar material hardships; but at least some of them were warmly greeted by the president of the university, were accepted comfortably by their colleagues who admired them for their scholarship, and bad access to large groups of more or less respectful students. It is a suggestive idea that the hostility they bad experienced in Europe, and the welcome that awaited them in America, were the respective offspring of the competing worldviews that, on a larger scale, propelled the two continents into battle with each other.

Let me tum to other high points in the life of the Boston branch of the Vienna Circle in Exile. As one would expect from a group that bad learned how to persevere and gain public attention against all obstacles in Europe, their ambition in America was also not confined only to the local scene. As I mentioned, the local Inter-scientific Discussion Group converted itself in 1947 (with some grant funds from the Rockefeller Foundation) into the International Institute for Unity of Science, housed in the American Academy of Arts and Sciences in Boston. The group was now trying to be a successor to the old intellectual discussion circle, as well as to the Ernst-Mach-Verein with itsexternal, proselytizing functions, including public lectures and a publication series. It also aided Neurath's work in exile, first in Holland and then in England, and supported the enormous labors of the Encyclopedia, launched by Neuratb, Camap, and Morris at the University of Chicago Press.

Figure 6 is a draft of the description of the Institute as it presented itself to the outside world. Let me point to a few interesting sections. One of the outreach aims was "to stimulate the interest in these issues among college students, college faculties, and among the public at large." The Institute arranged an essay contest for students all over the United States. It edited the Encyclopedia. It started research and projects in the fields of semantics, logic of science, and sociology of science. It arranged discussion groups and meetings at several places. It had become a voting member of the International Union for the Philosophy of Science, and there were other international connections-- French, British, Dutch, Swiss, Scandinavian, Belgian, and Italian. And it cooperated with the "movement for general education." Thus, soon after the war was over, contact had been reestablished from the Boston area with countries in which there had been members of or sympathies for the Vienna Circle, and new activities abounded.

When an institution gets confident enough, it prints a letterhead. Figure 7 is a letter from the Institute for the Unity of Science, displaying its Board of Trustees. Philipp Frank is president; Charles Morris, vice president; Ernest Nagel, vice president; Milton R. Konvitz, secretary-treasurer. Other members are Bridgman, Egon Brunswick, Camap, Feigl, Carl Hempel, the biologist Hudson Hoagland, Roman Jakobson, Quine, Hans Reichenbach, Harlow Shapley, and S. S. Stevens.

The letter itself shows that a series of parallel seminars in the forthcoming meetings would concentrate on a single topic each: for example, linguistics and semantics, communication and cybernetics, science and politics, and science and values. Each of the four different groups would have its own monthly meeting, and seriously work on projects and perhaps on publications. 
As it turned out, the American Academy already had working groups on Science and Politics and on Science and Values, and so the Institute folded those activities in with the Academy's, and on its own ran only the Linguistics and Semantics seminar and the Communications and Cybernetics seminar. Wiener's seminal book on cybernetics was new and difficult to read. The Dictionary of Scientific Biography was later not very kind to Wiener's work, calling"...Cybernetics a badly organized work."12But the group was eager to hear Wiener tell what it was all about, and he was quite ready to do so.

When Minutes of meetings were not kept or did not survive, one can sometimes get a taste of the discussions from letters. There is one to Henry A. Murray (30 April 1951, from Ralph Burhoe, Secretary of the American Academy) which pleads with him to address the group on the topic, what psychological studies can do for the "clarification of value judgments." At the previous meeting, LeCorbeiller had delivered himself of what the letter called a "bomb blast", saying "it was nonsense for such a group [with so many physical scientists] to discuss the problem of values, since there existed, in the wake of Freud, a special science" that is making progress, in comparison to which all others are "amateurish and utterly inadequate." The letter concludes that while those present had recognized "that it would be desirable to include at least one psychologist, psychiatrist, or psychoanalyst in the group, someone implied that this would be practically futile since this species of human cannot communicate with physical scientists, both because of a lack of a common language and because of basic emotional antipathies." There is no record of how Murray, largely a Jungian, dealt with this challenge.

Among other meetings one would like to have had recorded were those beginning with presentations by Hermann Bondi on the "Continuous Creation Hypothesis" (17 Nov. 1953); by Karl Popper on "Some Reasons for Discarding our Philosophy of Meaning" (10 March 1950, during his stay at Harvard to give the William James Lectures); by John von Neumann (Feb. 28, 1946) on the "Theory of Games and Economic Behavior", followed a month later by Oskar Morgenstern on further applications to economics; by Howard H. Aiken (Jan. 17, 1947) on the first large electromechanical computer, the Mark I, "Automatic Calculating Machinery", with Leontief as moderator; and by Dennis Gabor on "Information Theory and Scientific Method" (9 Oct. 1951). By that time the group's secretaryship had passed on to a young neurophysiologist named Walter Rosenblith. Among the new attendees one finds the name of the prominent electrical engineer Jerome Wiesner, who later became president of MIT, with Rosenblith serving as his Provost.

One topic that interested some members of the group rather intensely was Social Physics. One of my notes records the suggestion:"Get J. Q.Stewart." Professor Stewart was an astronomer at Princeton University, but deeply devoted to his idea of Social Physics, a project to quantify the everyday behavior of people in order to find its descriptive laws--for example, the relation between the distances between two cities and the number of telegrams that went back and forth between them. His book, Social Physics, is full of mathematical relationships exploring behavior patterns that might be deduced from national statistics. Somehow he persuaded the 
group, and perhaps above all Bridgman, to spend quite a lot of time on his ideas. For example, there is a sheet (Fig. 8) from the "Fourth Conference on Social Physics", held in Randolph, New Hampshire, a small village where Bridgman had his summer house. With some money from the Rockefeller Foundation a variety of experts were brought together to examine the claims of Stewart. Voluminous Minutes were kept and still exist. The whole topic has the sound and smell of the kind of enthusiasm that occasionally engaged persons such as Neurath in the heyday of the Vienna Circle, a mixture of physics and sociology.

Social Physics tried to apply to the social sciences the teachings of the physical sciences, and attempted to catalogue and describe, in a rather Machian fashion, the stimuli and responses in the social sciences with respect to social values. The crucial factors were "social energies", which couldbe represented by physical terms. These energies included meaning, feeling, and authority. Social Physicists searched for metaphors or analogies between the physical and social sciences, though there was, quite explicitly, no attempt to set up physics over sociology and the humanities.

In retrospect one must say that for a group of academics that essentially invented itself, the conferences, publications, and other activities ofthe Institute for the Unity of Science--of which I have given by no means an exhaustive account--came to look more and more professional. Take for example the $21 / 2$-day-long, ecumenical and elaborate conference on "Validation of Scientific Theories", held in December 1953. It was sponsored by the American Academy, the Institute for the Unity of Science, the Philosophy of Science Association, the American Association for the Advancement of Science, and even "cosponsored" by the National Science Foundation. The speakers and panelists included Frank, C. West Churchman, Henry Margenau, Robert K. Merton, Gustav Bergmann, Carl Hempel, R. B. Lindsay, Bridgman, Adolf Gruenbaum, Else Frenkei-Brunswick, B. F. Skinner, Michael Scriven, Wolfgang Kohler, N. Rashevsky, Warren McCulloch, Henry Guerlac, Alexandre Koyre, Karl Deutsch, Edwin Boring, and RobertS. Cohen, then at Wesleyan University. (Fig. 9 is the "tentative program", circulated to the Program Committee, with its original markings.) The main papers were first published in 1954 and 1955 in several issues of the Scientific Monthly, and later in a widely distributed book, edited by Frank (The Validation o[Scientific Theories. Boston: Beacon Press, 1957).

I hope this survey, based chiefly on some documents in my "archive" of this group, has provided a feeling for one of the transplanted parts of the Vienna Circle, specifically its Boston-area history, its aims, its members, its friends and interested visitors. But by 1955 or so, the group began to disintegrate, mainly for the same reasons that led to the passing of logical positivism and its successor into the shadows. As Lewis A. Coser has written, they were victims of their own success; I think he meant by this that their ideas had become so adapted to local conditions and so widely internalized that they had lost their original energy and relevance. Perhaps equally or more important were the various challenges from Quine and the late works of Wittgenstein, as well as from Alexandre Koyre and Norwood Russell Hanson, each of whom by the end of the 1950s had opened up new ways for thinking about the interaction between science and philosophy. Symbolically also, both 
Bridgman and Frank formally retired from the University in the mid-1950s, so the main driving energy of the Boston group was greatly reduced. And in the intervening decades, the pendulum has swung to the other extreme. Apart from the few centers where logical positivism, logical empiricism, and its successors have become fruitful historical research sites, the denigration of what these serious scholars tried to do is as total as it is usually uninformed. A useful (and amusing) account of the current situation by D. C. Phillips of Stanford University begins as follows:

Nowadays the term "positivist"is widely used as a general term of abuse ... Social scientists who either bandy the term about, or are the recipient of it as an abusive label, are so confused about what it means that, while the word is full of sound and fury, it signifies nothing. The anti-positivistic vigilantes, who realize nothing of this, still claim to see positivists everywhere.13

At any rate, the meetings of the I.U.S. continued to 1958; but what was now needed was a rather new effort that would build on the basis of the I.U.S. with youthful energy. And this is precisely what happened. RobertS. Cohen had become Secretary of the group; and after seeing to it that as an organization it was given a decent burial by dissolution-with its remaining small funds transferred to the Philosophy of Science journal and the newly formed Philosophy of Science Association-he and his colleague Marx W. Wartofsky founded the inter-university Boston Colloquium for Philosophy of Science in 1959, located at Boston University, and still going vigorously. During its early years, Frank and other former members of the I.U.S. contributed regularly, and thereby smoothed the transition.lndeed, the second volume of the Proceedings of the Boston Colloquium, the series that became internationally known under the title Boston Studies in the Philosophy of Science, was a Festschrift dedicated to Frank. 14

I end with a personal remark. As I fully appreciated at the time, for a young person, participating in these activities was immensely stimulating.Perhaps precisely because of the high density of superb intellectuals, the various leading members of the group, brought together by remnants of the Vienna Circle, made no effort to exact any uncomfortable agreements, but relished in the most wide-ranging debates. I never felt that I had to follow, or to struggle against, any doctrinaire master. When my own first historical studies convinced me of the need to add Thematic Analysis to the older tool-kit of the historian and philosopher of science, I sensed only encouragement, instead of the kind of opposition one might have expected from rock- hard logical empiricists. If I had to characterize the members of that group in one sentence, I would focus on their unlimited curiosity and their generosity of spirit, a generosity which seemed founded on their ever-youthful self-confidence. When future historians study the philosophy of science during the middle part of this century, I hope they, too, will remember this.

\section{NOTES}

1. For original excerpts from the diary, see Manfred Geier, Der Wiener Kreis. Rowohlt: Reinbek bei Hamburg 1992, pp. 49-50. 


\section{REPORT-DOCUMENTATION}

2. See G. Holton, "Ernst Mach and the Fortunes of Positivism in America", in Isis, lobi. 83,1992, pp. 27-60, or chapter 1 in G. Holton, Science and Anti-Science.Cambridge, MA: Harvard University Press 1993. These are earlier versions of my essay, "From the Vienna Circle to Harvard Square: The Americanization of a European World Conception", in Friedrich Stadler (Ed.), Scientific Philosophy: Origins and Developments.Dordrecht/Boston/London:Kluwer Academic Publishers, 1993. The present essay essentially continues the accountofthose developments into the $1940 \mathrm{~s}$ and 1950s.

I gladly acknowledge help with documentary research from Myles Jackson and Hasok Chang, and excellent comments on an early draft from RobertS. Cohen. Versions of this essay were presented at a lecture at the Institut Wiener Kreis in April 1993, and atthe Boston Colloquium for Philosophy and History of Science in December 1993.

3. Mach had first turned to Privatdozent Frank in 1910 for help when Mach was puzzled by the new physics. See Holton, Science and Anti-Science (Ref. 2), chapter 2.

4. E.g., seeR.S. Cohen,"Dialectical Materialism and Camap's Logical Empiricism", in P. A Schilpp(Ed.), ThePhilosophyofRudolfCarnap.LaSalle: Open Court,1963, pp. 99-158, for remarks on Hans Hahn. In Neurath's work, there was a continual emphasis on placing the social sciences into the framework of Unified Science; this had inherently progressivist political implications for Neurath. See, for example, "Empirical Sociology" in Otto Neurath: Empiricism and Sociology, Marie Neurath and RobertS. Cohen (Eds.), Dordrecht: Reidel,1973, pp.319-421, and "Sociology in the Framework ofPhysicalism" in Neurath'sPhilosophicalPapers 1913-1946, RobertS. Cohen and Marie Neurath (Eds. and Trans.), Dordrecht: Reidel,1983, pp. 58-90.

5. Published asP. Frank, "Introductory Remarks", in "Contributions to the Analysis and Synthesis of Knowledge", Proceedings of the American Academy of Arts and Sciences, Vol. 80, nr. 1, July 1951,"published in cooperation with the Institute for the Unity of Science", pp. 5-8, on pp. 7-8.

6. The chapters ranged from P. Frank, "The Logical and Sociological Aspects of Science" to Else Frenkel-Brunswick, "Psychoanalysis and the Unity of Science."

7. See Ref. 2

8. Ref. 4, p. 5.

9. $\quad$ Proceedings, lobi. 80, nr. 1,July 1951, p. 9.

10. The bibliography was completed in 1951 with the assistance of Bernard Barber, and it was published in May 1952 by the American Academy of Arts and Sciences in its Proceedings, Vol. 80, nr. 2.

11. I have placed copies of these, and of many other documents referred to in this account, in the archives of the Institut Wiener Kreis (Vienna) and of Harvard University (Pusey Library, P. Frank file).

12. Hans Freudenthal, entry for Norbert Wiener in C. C. Gillispie (Ed.), Dictionary of Scientific Biography, Vol. XIV, 1976. The biography of Wiener by Steve J. Heims, John Von Neumann and Norbert Wiener: From Mathematics to the Technologies of Life and Death, Cambridge, MA: MIT Press, 1980, indicates the early struggles of Wiener and of his audience.

13. D. C. Phillips, The Social Scientist's Bestiary: A Guide to Fabled Threats to, and Defences of, Naturalistic Social Science. Oxford: Pergamon Press, 1992, chapter 7 ("Positivism"), on p.95.

14. RobertS. Cohen and Marx W.Wartofsky (Eds.), In Honor of Philipp Frank, Vol. 2 of Boston Studies in the Philosophy of Science. New York: Humanities Press, 1965. 
Figure 1

1

FIFTH INHERTATIONAI CORGRESS FOR THE UTITY OF SEIEKGE

Iogis of Science

Harvard Uriversity, Eept. 3-9, I\$39

Sunday, Sept. 3, 8 PI. Sroker. Illot Fouse. Cpening of the Congress. President James B. Conant, F. P. Bridgman, C. Neurath, C. Korris.

rondiy, Sept. 4.

Yorning, 9-I2 AY.

General Session. T: e Orificetion of the Sciences Emerson Hair, Foor. D.

George Sarton, The tistorice: Basis of Philoscyhical Urificetion.

P. F. Bridsman: The Fressupositione cf the Trity cf Science

otto Neuratt: The Soczel Sciences ard Enifiec Scierce

Afternoon, 2:30-5:30 PY.

Generel Sessioni Science end Implracisr

Imerson Fall, R.oor D.

Jłrgen Tórkenser., Expirisisz anc the Unit. c: Science

Fens "eichenbech: $\mathrm{Cr}$ Learing

Ficherd von lisges: On a Textbock of Ezpirzcisr

Teusiat, Sept. 5 .

Morning, $0-12$ Al:.

General Session: Generel Aspects of the Unity of Science Emerson Holi, Roor. D.

Hesie: I F. Curry: Rerrerks on the Dfinition and Keture of l'stheratics

Ti.F.G.Swann: The Sienificance of Scientific Theorieg Rudolf Carnap: Language and Analysis of Science.

Afternoon, 2:30-5:3C PR:

Concurrent Sessions:

A. Problems in the Cnity of Science, Fmerson Hell, Roor A. horace I:. Kalien: The Meanings of Unity

Susonne $Y$. Langer: The Score of Problems es the Iimlt of Inteliecturl "Fielden.

Herbert Feigl: Cnity of Science and Unitary Science

Sidney Hook: John Dewey and Physicalist:

B. Physics, Emersor. Hall, Roor F.

R. B. Lindsay: The yearine cf liessurerent in Fhysics

Louis Rouster: Les nouvelies logiques de le recenioue

querticue et l'expirisme radical

F. Weismann: Is Logic Aprlicatie to the whole of physics?

Fidnesday, Sept. $\epsilon$.

Norning $0-12$ Ar.

Concurrent Sessions:

A. Psychology and the Syster of the Sciences, Emerson HeI1, A Carroli C. Pratt: The Subject Vatter of Payciology in Kelation to Generel Science 
2

F. Oppenheim enc $K$. Grelling: Logical Anelysis of "Gestalt" ag a Functional Khole.

Herry S. Leonerd: Gestalt Fsychology and Physicalksm.

Z. Biology and the Soclal Sciences. Emerson Hali, Foom $F$. Kur: Golastein: The Fetlonale of Biological Knonledge

Ralpt F. Gerard: Sore Social Irplicetzons of Biology

Lewrence I. Hendergor: A Relotior. of Physiology end the Social Sciences

Afternoon.

Ixhfbit of George Sarton's apparatus for the stucy of the

History of Science

Widener Ilbrary, 185-s 2:30 PR.

Tea $4: 30$

Thursciay, sept. 7 .

Yorning, S-12 A:.

Concurrent Sessiors

A. The Sociai and Humanistic Sciences, Emersor HaIl, Room $h$

Tiliciar. R. Dennes: Value Theory and the Sociel Sciences

Louis Wirtr: Values in Social Science

Charles Morris: Semotrc, the Socic-Humaniztic Sciences,

and the Unity of Science

Heinrick Gomperz: Unfified Sclence anc Velue

E. Obgervation and the Confiretion of Scieritific Theory,

Emereon Hell, Foom $F$.

Carl G. Hempei: The Logicel Strueture of Ampirical

Testans

Alexende= Fundheller: An Attempt at a Formal l'ethodoloe:

of Expiricel Systems

J. Iindenbaur tosissoon: On Coffirmetion

Af ternoc, $z: 30-5: 30$ PI:

Concurrent Sessione:

A. Languege and Science, Fmerson Hall. Roor $D$

D. C. Milliams: Iesignation and Empirical Certainty

Karl Feach: Syntey of Universal Ianguage

James F. Seniur: The Vernacular of the Laboratory

Kerl Buklez: Four General Agaun: tions in Theory cf Ienguage

P. Probeb1lity, Emersor. Hal1, Koom F.

Arthur H. Coneland: The Fole of Cbservetions in a Forre: Theory of Probobility

Sergei Feltelber: Threstolc Percertione and Frobobllit;

Herry largenau: Frobobility and Physical Inouiry

C. Scince and Society, Fmersor Hall, Foor A.

Edgar Zilsel: The Social Foots of Science

Fritz Schreier: Das Problem der Voreussege in

Psycholoeie und SOzioiogie.

Leo Eyrne: Atteinable Geins to Iducation from the Unity of Science liovement.

Friday, Sept. $\varepsilon$.

Yornine, $9-12$ All.

Concurrent Sessions:

h. Joint meeting with the History of Science Society.

Historic Attempts at the Encyciopedic Integration of Science Emerson Hell, Room D.

Werner vager: Centralizetion and Unification of Science in the School of Arigtotle 
Estelle De Lacy: Leibniz

George De Santilians: 'Lhe Encyclopedists

Talcott Parsons: Corte.

B. Joint meeting eity, the Associatzor for Sywtolic Iogis.

Problems in the Fistory end Theory of LoEic, Bmerson, $h$.

Korl Darr: Die metheretische Logit des Arnold Geulincx

Ernest Fogel: Charles S. Peirce, Dioneer of yodern Hepiricism

Alonzo Church: Schroder'a Anticipetzon of the simple Theory of Types

Barkley Rosser: The Introduction of Quentificetion

into a Three-Velued Iogic

s. C. Fleene: On the Tez "Anelytian in Logical syntax.

Afternoon, 2:30-5:30 Fi:

Concurrent Sessions:

A. Hethod in Psychology end the Socis l Sciences, Emersor, D.

S. S. Stevens: on the Probler of Sceies for the ressurepient ce Paychologica? Yagnitudes.

Ichr Somerville: Fethodcleical Fectors in the Advancement of the Sociai Sciences

F. Creedy: A l'otheretico-loe $2 c=i$ Theory of societ

Yurt iewan ond Kar: Korsch: Yethers tical Corstructs in Psyciology end Sociology.

3. Scince enc Nature, Emerour Heli, Foom

Rilisa F. Fontague: Illueion of Nominelism

A. C. Eenjarin: Jome Balistic Imrlicsticna of Cperaitor-

elsir, Coñstructs, Fypotheses, and Vagueness

Julius Krafy: Letaphysicel or Loglcai Interpretation of Losistic?

V. V. Zuine: A Logistical Appruaci to the Ontologicel Probier.

C. Papers in the Hastory cf Science, Emersor Heli, Room F. Tennes I. Davug. The Identity of Chinese and Furopean Aicherical Theory

Hans Kelsen: Die Entstehung des Yausalitgtsbegriffa. Frilinp Frenk: The Historical Position of Einstein's

Satmrdey, Sept. 9. Theory of Feletirity in the Evoluticn of Science

rorning, 9-12 Ar'.

Concurrent Sessions.

A. Froblems ir Logic, Bmerson Hall, Foom $A$.

Felis Koufmenn: Trutr, end Logic.

Yurt Grelling: A Logicel Theorynof Dezendence

Leon frod Chwisteh: Infinitely Smeli fiumers and

Alfred Terski: ?

Their Application.

Sclence and Engineering, Fmerson Hail, Room D.

Robert S. ioodbury; The History of Fnetneering and the

A. V. Parnv: Is Engindustriel Revolution

Nicholas ì. Obouthoff: Irpirico-logical fnd Teleclogical

Factors in Engineering

Closing Session: 12:15-1:00 PH., Emerson Hall, Room D.

Fieport of Committees.

Philifp Frank: Fevier of the Congress. 
Figure 2

INT HR-3CEENTIF'IC DISCUSSION GROUP

December 30, 1944

Dear Professor Grael:

Ti. Wh to thank you for spenking at our last me etIng and wlsh to invite you to joln our group and partic1pate in as many meetinss as you can.

Our group consists of versons in different flelds who feel that the extreme specialization within sclence demands as 1 to corrective an interest in the entire scient ir $1 \mathrm{c}$ edifloe. ie plan to hold meeting from ilme to time in ihich disousbions of different toplos will je led by competent Echolars.

The next meeting will oe held on Monday, January 3th, at the Harvard faculty Club at 7:30 P.H. Profensor 4. Pon Lises till lead a discussion on "Sense and ronsense in lodern Statistics." It will oe precesed oy dinner at the Haculty Clup at 6:30 P.14. Klndly notlfy Dr. Ph1lippe Le corbell ler, Cruft Ladoratory, Cambridge, if you can attend the dinner.

Sincerely yours,

The Committee:

\author{
Peroy 1. Bridman \\ Walter Cannon \\ Ph1l1pp Frank \\ Ph1l1ppe LeCorbe11ler \\ FasRliy 17 . Eeontief \\ Harlow Shapley \\ George Uhlenbeck
}


Figure 3

$$
\text { PROPOSED PROGRAM / 1945) }
$$

\section{Logic of Sclence}

Borderline between sclence and philosophy, if any.

Role of philosophical doctrines (as materlaliom, 1doalism, etc.) in science. Is this role tho same in physical science. Is this rale the same in physical sclence as in biology and soc10logy?

Folo of hypothesis and theory. Is it the samo in physics as in other Bciences? What is the connection between general theory and concrete facts?

polo of mathematics, of long chains of reasoning.

Degree of confirmation of an hypothes18. Is there a moesure for th1s degree? Folo of causel lows and statistical lawe in phyolcs, blology and soc10logy.

Do final laws (purposivenoss) play a role in any science?

The role of "time" in physics, biology and history.

Semantics and 1ts application in science.

Untty of sclence.

\section{Paychology}

Peychological besis of sclentific ectirity. Why do we belleve something? Degrees of bellef.

Pale of the observing subject. "Objectirity."

Bellef in inductive mothods.

Relation of introspection and behariorism.

Psychology of discovery.

Elographies. Clasolcal types of sclentists.

\section{Sociology of Science}

Influence of science on society and vice versa.

What do political and religious 1deologies have to do with the evolution of ocientific theorlee? What 18 the influence of the church, of Marxism, of Naz1am?

Under what conditions wero great discoverles mado?

Teaching of sclence. General ro, opectal sclence.

Contemporary merging of sclence and tochnique.

The role of the liberal beliof in progress. 
286

REPORT-DOCUMENTATION

Figure 4

Please sign 5akealing Fob., 1945

Oliva So Seficty

Waltar Pito

Raphuel Salem

ritió zhetriece

how Gurwitses

Eduin [ lekatowing

Pule corbeiller

y.t.chav

A. Apuegranes

V. Kmipt garti

R.r. inises

Pw Binty-a

G. E. Uhlembect

E.C. Tembe

MR. Suthe arens.

Refol Loguandicy.

Velix ermuchi

Culoging

Albert. B. Barajo- Couter

y. G. Becoln. Cou
R.th. Goodurim

aeras of Hotos

4. de Santillana

Haur Stachle 
REPORT-DOCUMENTATION

287

Figure 5

Inter-Sucuáque Discussion Gropp

$$
\text { Sixth meeling - March21.1445 }
$$

mar. and mue Rachare Alewo

Telly enmoni

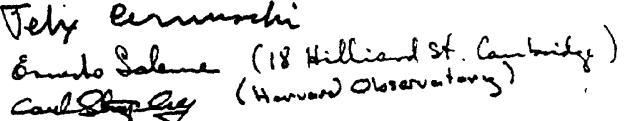

G. Kunthing Stampuli:

Lawrence Y'ine

Pisur 1. ahutimas

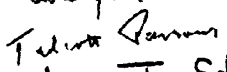

gotmon $T$ Edsall

Paul a Samuleor

viasnits Leartalt

Pouprea / tabureer Arwold hetser

Harlowshapley

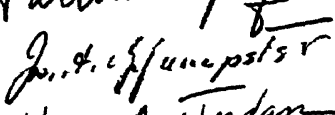

Heni $A$. Vondan

Geage \& Whimbeck
Hettur Mpusgrave

C.J. Bucene

PiLe Corbeillar.

Conold w P hing

P.W. Is midgmar

X. Wrens

A. Alictal

Sinat Br. Contfin

as coarabe lenter

w. Pits

CBClemuth

G.de Santiclave 
Figure 6

\section{INSTITUTE FOR THE UNITY OF SCIENCE}

American Academy of Arts and Sclences

28 Nowbury Street, Boston 16, Mass.

This Institute 1s a non-profit corporat1on which has offices in Ithace, New York, and Boston, Massachusetts. The charter says "The purposes for wh1ch the corporation is formed are to encourage the 1ntegration of knowledge by sclentific methods, to conduct research in the peychological and soc10logical backgrounds of sclence, to complle bibllographles and publish abstracts and other forms of literature with respect to the integration of sclentiflc knowledge, to oupport the internations movement for the unity of sclence, and to serve as a center for the continuation of the publications of the unity of sclence movement." The Institute attempts to stimulate the Interest in these 1ssues among college students, college faculties, and among the public at large.

The Inst1tute hes arranged an esear conteat for college otudente and pounc college graduates. It 1s editing the Incyclopedia of Unleled Sclence, published by the University of Chlcago Press. It is starting research projects in the flelds of eemantics, logic of sclence, and sociology of sclence. It arranges discussion oroups and meetings at several places in the United States.

It 1s a part of the International Union for the Philosophy of Sclence. It cooperates with the International Society for Significs (psycholinguistic studies) in Amsterdam and is organlzing, together w1th th1s Soclety, an international meetIng in Amsterdam. In cooperation w1th the European socleties for the philosophy of sclence (French, Brit1sh, Dutch, Swlss, Scandinavian, Belgian, and Italian), this Institute publishes comunications in the international journal "Synthese" which 18 published in Amsterdam and is the central organ of these groups. It can be subscribed to for $\$ 5$ a year through this Institute.

The Institute cooperates also with the movement for general education which attempts to Integrate the college curriculum and to break down the barriers between the departments. The Inst1tute arranges lectures and courses at different places in the Untted States.

It 1s supported by the Rockefeller Joundation and the Americen Academy of Arts and Sclences. The Institute is adminlstered by the following Board of Trustees:

\author{
Preeldent \\ Prilipp G. Frank \\ Barvard Unfvers1ty \\ V1ce President \\ Charles W. Morr 18 \\ Undversity of Chlcago \\ Vice President \\ Ernost Nagel \\ Columbia Univeraity \\ Becretary-Treasurer \\ Milton R. Konfltz \\ Cornoll UnIfersity
}

\author{
Percy W. Brldeman \\ Harvard UnIversity \\ Egon Brunowilk \\ Untversity of Cal1f. \\ at Berkeley \\ Rudole Carnap \\ Untversity of Chlcago \\ Berbert Fe1gl \\ Untversity of Minn. \\ Carl G. Bermel \\ Yale UnIveralty \\ Budson Bcagland

\section{Roman Jakobson \\ Hervard Untversity}

Wlllard V. 0. Quine

Barvard Untversity

Hans Relchenbach Untversity of Calle. at Ios Angeles

Barlow Shapley Bervard UnIversity

Stapley S. Stevens Harvard UnIvera1ty 
Figure 7

\section{Institute for the Unity of Science}

American Achormy or Arts and Sctences 28 Newsura Street

Boston 16, Masenchuserts

BOARD OF TRUSTES

\section{President}

Pumine G. Frans Harvand University

Vice President

Cunus: W. Mouns University of Chicago

Vice President

Evirer Naci.

Columbia University

Secretary-Treasurer

Minton R. Konvitz

Comell University

Pracy W. Bumanen Harvard University

Econ Brunewnce

University of Calif.

at Berkeley

Redolr Cuenas

University of Chicago

Hersert Fejar

Cuversity of Minn.

Cur G. Henare

Yale University

Hedsox Hoseruvd

IVorcester Foundation

Expenmental Biology'

Rosur JAsoseos

Harvard University

V'rinad V.O. Quine

Harvard University

Haws Rucamenca

University of Celif

at Los Angeles

Hunow Surur

Harvard Univerxity

Stoner S. Sravens

Harverd University
October 24, 1950

Dear S1r:

The Institute addresses 1tself to 1ts friends in an effort to gauge the interest in a new project, the formation of small study Eroups or seminars (In addition to the usual monthly general meet1ngs). Each seminar, in a sertes of informal monthly (?) meetings, would concentrate on a single topic throughout, for example (A) Iinguistics and Semant1c8, (B) Communication and Cyberzet1c8, (C) Sc1ence and Polltics, (D) Sclence and Values. The American Academy of Arts and Sclences, which cooperates with us in th1s as in our other programs, has already existing committees active in relation to topics (C) and (D), which I am informed would undoubtedly be glad to work with us in Bemlnars in these toplcs.

The well-remembered success of similar sroups in this area has shown that attendance of qualified and interested non-specialists and mature graduate students can be velcomed; thus one of the items (number 4) in the questionnaire enclosed 1s a request to you for the names of those to whom one or the other of our projected seminars may appeal.

\section{Iours very truly,}

The Program Comitteo

Percy W. BrIdgman

Karl W. Deutsch

Philipp Frank

Roman Jakobson

Philippe Io Corbelller

Frederick Mosteller

W1llard V. 0. Quine

Barlow Shaploy

S. S. Sterens

Richard von Mises

Gorald Holton (Secretary) 
Figure 8

FOURT RANDOLPR, NET RAMPSEIRE, CONFERENCE

ON SOOIAL PEYSICS

D1geat of Conclusions

$* * *$

The conference was held July 6-11 at the Mount Orescent House, as were the three preceding ones in July, 1950-1-2. Expenses were met from the Rockefeller Foundation grant to Princet on oniversity for the otudy of soclal physics, directed by Professor John Q. Stewart. Morning and evening sessions were held, while afternoons were left unscheduled for engojment of the Finte Mountain country.

Part 1c1pants, representing a wide variety of expertness, were Raymond Albright, theologian and church historian, Eplacopal Theological School, Cambridge, Mass.; Raymond E. Bassett, soc10logist, oniversity of New Hampshire; P. W. Bridgman, physiclat, Harvard Oniversity; Norman Dodd, banker and econom1st, New York, N. Y.; Ira M. Freeman, physic1st, Rutgers Oniversity; Paul A. Furrer, educator, The Hun School; James D. Fam1lton, b10logist and phys1c1st, Coll1p Laboratory, On17ersity of western ontar10; Alfred Joenssen, 1mporter, New York, N. Y.; Bernard 0. Koopman, mathemat1cian, Columbia University; John O. Macarthur, oolonel O. S. A. (ret.), edit or Armed Forces Ohem10al Journal; Duncan A. Maolnnes, phyalcal chemist, Rookefeller Institute (ret.); 0 . Edward Pendray, public relations counsel, New York, N. Y.; R. Rudenberg, electrical engineer, Harvard onlversity (ret.); T. Shedloviky, physical chemlot, pockerelier Inst1tute; John Q. Stewart, phys1c1st and astroncmer, Princet on OnIvers1ty; W. Frank Sutherland, electrical eng1neer and admin1strator, Toronto Rydro-Electric syotem.

While no formal statement of conclusions has been subscribed to by members, substantial agreement on the following polnts was reached in the discussions:--

Social physics has attained the threshold of a period when more rap1d development 18 foreseen and should be urged. It now presents the eramework of an inclusive pattern for desoription of social phenomena in the large, and for alding in the formulation of many types of ooolal policies. This pattern 1s set by two main 1deas drawn in large part from physical sclence, but nonetheless humanfstic in et ruoture and application. 
Figure 9

\section{Institute for the Unity of Science}

Amenche Achormy of Axts and Sarences 28 Nrweuxy Snirex

Boston 16, Mnsencruserts

Baned of TRUstes

Presidene

Prowos G. Fowrs.

Hervard Univecix

$V$ ice Presides:

Crume W. Moside

Univeraty of Chica:

Vice Presidant

Exprar Nect.

Columbia Univerity

Secreenery-Trosioner

Minrow R. Konsm

Comell Univerasy

Peacr W. Bameaner

Harvard Univessity

Ecos Beunemax

Unversty of

Ropoes Cuene

Universty of Chicapo

Hrawer Fmen

University of Minn.

Cuer G. Header.

Yale Universicy

Howeons Hoscuss

Worcester Founderion

Roven JNroevon

Roveus Jurcaneser

Wreno V.O. Qons

Herverd Univerairy

Haws Rucomprach

Universty of Calif.

at Los Angeles

Humow Sunur

Harvard Univering

Sturer S. Snvace

Harvard Univeraty
Novermber 10, 1953

Professor Qerald Bolton

Dept, of Physics

Harvard Untrersity

Cambridge, Massachusette

Dear Professor Holtons

After having received your letter containing your preference in the choice of topics for the Christmas Conference, I composed a tentative program in cooperation with those members of the conmittee wom I could contact personally. The following is the proposed program.

Sunday, Dec. 27, 2 p.m. Section I of the MMS.

Sympapium: Reasons for the Acceptance of Scientiflc Theories.

Chatrmans R.Seoger (llational Solence Foundation)

Panel Speakers: P.Frank(Harvand) TTho Varity offeasons for the Acceptanco of Theortesn. W.Churchann(Waym U.) nThe Role of Decision in Inductive Inference", B.Hoor (Russian Besearch Center, Herrard) mon the Role of Political Ideologies in the icceptence of Thoorlegll.

The aforementioned meeting takes place in the Hub Roon of the Sheraton Plaza Hotel. All following symposia will take place in the Inarican Icadom of Arts and Sclences biulding, 28 Newbury St., Boston.

Mandar, Dac. $28,9,30-12830$

Syruposium: The Present State of Operational1sm.

Chatrman: B.Mergenau(Yale)

Panel Speakers: O.Bergmann (Gown) "Interpretations and Misinterprotations of Operationaliam", C..Hempel (Yale) "A Logical Appratsal of Operationalism", R.B.IfIndsay (Brown) "Oparationalion Finaseasedn.

Invited Discussants: P.W.Bridgman(Harvard), H.Fe1gl(Minnesota), A.Grunbaum (Iehtgh U.), S.S.Stevens(Harvard), R.Senger (National Science Foundation). 
Mondery, Dec. 28, 2:00 - 5,00 P.m.

Symposiurs Poychoanslysis and Sclentific Wathod.

Chatrmane H.Folel (M1nnesota)

Panel Speabers: E.Frenbel-Brunsurik(Berbeley) wThe Meaning of Poychoanalutie Concepts and the Confirmation of Psychoanalytic Theorieg", B.F.Skinner (Barvard) "Critique of Poychoanalutic Concepts and Theories".

Invited Discussantes M.Iean(Brooklon Callege), J.Richfield(CIncinnati), M.Scriven (MInnssota).

Tusedar, Dec. $2 \hat{q}, 9: 30-12,30$

Symposime Organisen and Machtre.

Chndrones G.Wiald (Herrard)

Panel Speajers: W.Kohler(Swarthore) will speak from the philosopicical and poychological viewpolnt. N.Reshovak (Chicago) from the viewpoint of mathematical biophsics. W.McCuloch(M.I.T.) n " Nervomechanisas. B.Mandelbrot (Sorbonne) Mrbe Kechanism of Vatural Language".

Invited Discussantss E.Nagel(Colmbia).

Tresday, Dec. $2 \hat{q}, 2800-5800$ p.llo

Symposiun: Science as a Social and Historicel Pbanomenon.

Chatsenes G.Bolton(Harvand)

Panel Speakers: H.Guerlac(Cornell) "Impact of Social and Polltical Events of the French Revolution upon the Scientists of that Time", E.Boring (Harrard) "On tine Role of the 2eitgeist in the Formulation of Theories and the PRoblem of Creativity", L.Koyse(Sorbonne) "The Influence of Philosophiral Trends on the Formulation of Scientific Theoriesn.

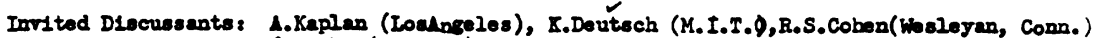
B. Barber(Barnard). +R.K Matom, Lduntria

Flease write me ang auggestions about possible alterations. All members of the comnittee are regarded as invited discussants for all symposia. If you have no hotel accomodations reserved by the AAs, please write as early as possible to the chairman of our local comnittee, Prof. G.Holton, Dept. of Physics, Harrard University, Cambridge, Masabahisetts.

Whth the expressions of ay beat regards, very aincerely joure,

Porsea

$$
\begin{aligned}
& \text { Pht11pp O. Frank } \\
& \text { (1) } \left.x_{1}, c\right) \longdiv { t _ { y } }
\end{aligned}
$$

